\title{
Effects of Drought and Salinity on European Larch (Larix decidua Mill.) Seedlings
}

\author{
Ioana M. Plesa ${ }^{1,2}$, Sara González-Orenga ${ }^{2}$, Mohamad Al Hassan ${ }^{2,3}$, Adriana F. Sestras ${ }^{1}$, \\ Oscar Vicente $^{2}$ (i), Jaime Prohens ${ }^{4, *}$ (i) , Radu E. Sestras ${ }^{1}$ and Monica Boscaiu ${ }^{5}$ \\ 1 Faculty of Horticulture, University of Agricultural Sciences and Veterinary Medicine of Cluj-Napoca, \\ 400372 Cluj-Napoca, Romania; ioanaplesa13@gmail.com (I.M.P.); adriana.sestras@usamvcluj.ro (A.F.S.); \\ rsestras@usamvcluj.ro (R.E.S.) \\ 2 Institute of Plant Molecular and Cell Biology (IBMCP, UPV-CSIC), Universitat Politècnica de València, \\ Camino de Vera s/n, 46022 Valencia, Spain; sagonor@etsia.upv.es (S.G.-O.); \\ mohamad.alhassan@plantandfood.co.nz (M.A.H.); ovicente@ibmcp.upv.es (O.V.) \\ 3 The New Zealand Institute for Plant \& Food Research, Auckland 1025, New Zealand \\ 4 Institute for Conservation and Improvement of Valencian Agrodiversity, Universitat Politècnica de València, \\ Camino de Vera s/n, 46022 Valencia, Spain \\ 5 Mediterranean Agroforestry Institute, Universitat Politècnica de València, Camino de Vera s/n, \\ 46022 Valencia, Spain; mobosnea@eaf.upv.es \\ * Correspondence: jprohens@btc.upv.es; Tel.: +34-963-879-424
}

Received: 16 April 2018; Accepted: 31 May 2018; Published: 4 June 2018

\begin{abstract}
Larix decidua, the European larch, is not normally affected by drought or salinity in its natural habitats, but it may be when grown as an ornamental tree, by the widespread practice of winter de-icing of mountain roads with $\mathrm{NaCl}$, and because of global warming-induced environmental changes. The responses of two-month-old larch seedlings to 30 days water deficit (withholding irrigation) or salt stress $(150 \mathrm{mM} \mathrm{NaCl})$ treatments were studied by determining stress-induced changes in several growth parameters and biochemical markers (ion and osmolyte contents, level of oxidative stress, activation of enzymatic and non-enzymatic antioxidant systems). Both treatments caused the inhibition of growth, degradation of photosynthetic pigments, a small increase in malondialdehyde (MDA, an oxidative stress biomarker), and the activation of antioxidant enzymes: superoxide dismutase (SOD), catalase (CAT), ascorbate peroxidase (APX), and glutathione reductase (GR). In all cases, salinity appeared to have stronger effects on the seedlings than water deficit. The presence of relatively high concentrations of glycine betaine, both in control and stressed plants, may represent a constitutive mechanism of defence against stress in European larch. Additionally, other responses were specific for salt stress and included the activation of $\mathrm{K}^{+}$transport from roots to shoots and the accumulation of Pro as an osmoprotectant.
\end{abstract}

Keywords: European larch; drought; salinity; ion homeostasis; antioxidants; osmolytes

\section{Introduction}

Climate change represents the most significant challenge for the environment-and for mankind-in the 21st century [1,2]. Regarding the reduction of agricultural yields and food production, arid and semiarid regions will be the most affected areas in the world, due to longer and more intense droughts and to secondary salinisation in cropland cultivated under irrigation [3]. However, the predicted environmental changes will also affect forests in temperate climate zones, the natural areas of growth for a large number of tree species. Some of these species may present a high genetic diversity and phenotypic plasticity, allowing the existing populations to tolerate the changes in their natural habitats; otherwise, if they are unable to cope with the new environmental conditions, they 
may become extinct [1]. Comparative analyses of the variability within and between species in their physiological responses to environmental stress factors should provide valuable information on the adaptability of a given species - and of a particular forest ecosystem as a whole-to the consequences of climate change [4]. Therefore, to improve the current and future status of our forests, it is essential to promote research focused on gaining a better knowledge of the responses of forest trees to abiotic stress, in combination with proper reforestation techniques.

The European larch (Larix decidua Mill.) has a disjunctive distribution in Europe, with a centre in the subalpine belt of the Central Alps. Besides its interest as an important timber species in Europe, L. decidua also has excellent potential for landscaping and is highly appreciated as one of the few coniferous species with deciduous foliage [5].

In its natural habitats, European larch is found in the montane and sub-alpine range, although in many mountain systems, it often surpasses $2000 \mathrm{~m}$, constituting the upper boundary of the forest. In more northern areas, European larch stands can be found at much lower levels. Regarding environmental requirements, $L$. decidua needs between 600 and $1000 \mathrm{~mm}$ annual precipitation and can tolerate very low temperatures, even below $-30{ }^{\circ} \mathrm{C}[6]$. On the other hand, European larch is a species with a pioneering behaviour and, as such, heliophilic and tolerant to a wide range of soil conditions. It develops better in deep soils, well-structured and aerated, with a pH between 5.5 and 7 [7]. As drought and salinity are not common environmental limiting factors affecting European larch in its natural habitats, not much effort has been invested in the study of the responses of this species to salt or water stress. However, climatic conditions will no doubt change in the future, to a greater or lesser extent, and especially in the more southern areas of Europe, which will suffer more frequent and more intense drought periods; thus, European larch masses in those areas will be directly affected by drought episodes. Water stress is one of the most damaging factors for the success of reforestation actions. European larch does not grow naturally in saline environments but can be affected by relatively high salt concentrations in stands close to mountains roads, due to the use of large amounts of $\mathrm{NaCl}$ for de-icing in winter, a widespread practice in many countries. Also, European larch is often used as an ornamental tree, grown in parks and gardens where the trees may be irrigated with low-quality water, with high concentrations of salts. However, there is limited information available on the responses of this species to drought and salinity and, especially for the latter, experimental data are very scarce.

All plants, regardless of their tolerance degree, react against environmental stress factors through the activation of a series of conserved responses, which are common to different types of abiotic stress. These responses encompass diverse physiological, biochemical, and cellular processes in a specific environmental context [8,9]; they include, in most cases, the inhibition of photosynthesis and plant growth $[10,11]$, the accumulation of different osmolytes, the activation of antioxidant systems, and the expression of specific defence proteins [12-16]. In addition, particular stress conditions may elicit specific response mechanisms, such as the control of ion transport and ion homeostasis at high salinities [17], or the cold-induced synthesis of antifreeze proteins [18]. Osmolytes are of particular relevance since, apart from contributing to cellular osmotic adjustment under stress, they play essential roles as 'osmoprotectants'; they act as low-molecular-weight chaperons in the direct stabilisation of proteins, membranes, and other macromolecular structures under conditions of cell dehydration, as reactive oxygen species (ROS) scavengers, or as signalling molecules in the transduction of stress stimuli [19-21]. Activation of antioxidant systems to prevent or reduce oxidative damage to proteins, membranes, and DNA, is also a general reaction to abiotic stresses, which cause oxidative stress through the generation of ROS [16,22-25].

Antioxidant enzyme activities that can be induced as a response to stress include superoxide dismutase (SOD), catalase (CAT), ascorbate peroxidase (APX), peroxidase (POD), glutathione reductase (GR), and monodehydroascorbate reductase (MDAR) [22]. Non-enzymatic antioxidants, such as vitamins $C$ and $E$, carotenoids, glutathione, or phenolic compounds, especially the subclass of flavonoids, also contribute to maintaining the cellular redox equilibrium under stress conditions [23]. 
We hypothesise that Larix decidua seedlings are affected by drought and salinity and may utilise similar response mechanisms to both types of stress, involving osmolyte biosynthesis and the activation of antioxidant mechanisms. To check this hypothesis, we have applied water deficit and salt stress treatments to the seedlings, under controlled greenhouse conditions, and then evaluated, in stressed and control plants: (a) growth parameters; (b) photosynthetic pigments levels; (c) monovalent ions in roots and needles, (d) contents of common osmolytes; (e) the degree of stress-induced oxidative stress by quantification of malondialdehyde (MDA), a reliable oxidative stress biomarker; (f) total phenolic compounds and flavonoids, as examples of non-enzymatic antioxidants; and (g) the specific activities of major antioxidant enzymes. The results obtained may help to design and implement conservation and reforestation programmes for European larch in the context of climate change, as well as its use in landscaping and as an ornamental tree in urban areas.

\section{Materials and Methods}

\subsection{Plant Growth and Stress Treatments}

Plants were obtained from seeds sampled in a tree nursery near Cluj-Napoca, Romania. Seeds were sown on a mixture of peat $(50 \%)$, perlite $(25 \%)$, and vermiculite $(25 \%)$. Seedlings were grown individually in standard $1 \mathrm{~L}$ pots placed in plastic trays measuring $40 \times 50 \mathrm{~cm}$ (12 pots per tray). During the first two months, the pots were watered by adding $1.5 \mathrm{~L}$ of Hoagland's nutrient solution to each tray [26], twice a week. At the end of this period, stress treatments were started and were prolonged for 30 days. Control plants were watered twice a week with $125 \mathrm{~mL}$ of water per plant, whereas for the salt treatment, the same volume of a $150 \mathrm{mM} \mathrm{NaCl}$ solution was used. This concentration was selected according to our previous experience on coniferous species [27] and some preliminary experiments on L. decidua seedlings, as a non-lethal salt treatment causing measurable inhibitory effects on seedling growth. Before watering, for removing the salt that may accumulate on the bottom of the trays, these were washed and dried. Plants subjected to water stress were not irrigated at all during the 30 days of treatment. Seven biological replicas (individual seedlings of the same age and size) organised in a completely randomised design were used per treatment.

\subsection{Substrate Analysis}

Electrical conductivity $\left(\mathrm{EC}_{1: 5}\right)$ of the substrate in the pots was measured after the treatment. Soil samples were collected from each pot, air dried, and then passed through a 2-millimetre sieve. A soil: water suspension (1:5) was prepared in deionised water, mixed for one hour at $600 \mathrm{rpm}$ and $21^{\circ} \mathrm{C}$, and filtered through filter paper. $\mathrm{EC}_{1: 5}$ was measured with a Crison 522 Conductivity-meter, and expressed in $\mathrm{dS}^{-1}$.

Soil moisture was determined by the gravimetric method: a fraction of each soil sample was weighed (SW), dried in an oven at $105^{\circ} \mathrm{C}$ until reaching constant weight, and then weighed again (DSW), and the soil water content was calculated as:

$$
\text { Soil humidity } \%=[(\mathrm{SW}-\mathrm{DSW}) / \mathrm{SW}] \times 100 \text {. }
$$

\subsection{Analysis of Plant Growth and Dehydration of Samples}

During the experiment, the seedling length of all plants was measured every third day; at the end of the treatments, seedlings were sampled, and the length and the total weight of shoots were determined. For the dehydration of samples, some of the needles were weighed (FW) and oven-dried at $65{ }^{\circ} \mathrm{C}$ until reaching a constant weight (DW), typically $72 \mathrm{~h}$. The water content of the needles, as a percentage of the fresh weight, was calculated by the formula:

$$
\mathrm{WC} \%=[(\mathrm{FW}-\mathrm{DW}) / \mathrm{FW}] \times 100 .
$$




\subsection{Photosynthetic Pigments}

Chlorophyll a (Chl a), chlorophyll b (Chl b), and total carotenoids (Caro) were quantified by the method described in [28]. A total of $50 \mathrm{mg}$ of fresh needles was extracted in $10 \mathrm{~mL}$ of $80 \%(v / v)$ ice-cold acetone, by mixing overnight in an orbital shaker. Following a $10 \mathrm{~min}$ centrifugation at 12,000 rpm, the absorbance of the supernatant was measured at 663,646 , and $470 \mathrm{~nm}$. Calculation of pigment concentrations was done according to the following equations [28]:

Chl a $\left(\mu \mathrm{g} \mathrm{mL}^{-1}\right)=12.21 \times\left(\mathrm{A}_{663}\right)-2.81 \times\left(\mathrm{A}_{646}\right)$;

Chl b $\left(\mu \mathrm{g} \mathrm{mL}^{-1}\right)=20.13 \times\left(\mathrm{A}_{646}\right)-5.03 \times\left(\mathrm{A}_{663}\right) ;$

Caro $\left(\mu \mathrm{g} \mathrm{mL}^{-1}\right)=\left(1000 \times \mathrm{A}_{470}-3.27 \times[\mathrm{Chl} \mathrm{a}]-10 \times[\mathrm{Chl} \mathrm{b}]\right) / 229$

Chlorophyll and carotenoid contents were finally expressed in $\mathrm{mg} \mathrm{g}^{-1} \mathrm{DW}$.

\subsection{Monovalent Ions}

Contents of sodium $\left(\mathrm{Na}^{+}\right)$, potassium $\left(\mathrm{K}^{+}\right)$, and chloride $\left(\mathrm{Cl}^{-}\right)$ions were determined in the roots and needles of all seedlings. Measurements were performed according to Weimberg [29]; the extracts were prepared by incubating the samples $(50 \mathrm{mg}$ of dried and finely ground plant material suspended in $15 \mathrm{~mL}$ of water), for one $\mathrm{h}$ in a boiling water bath, followed by filtration through a $0.45 \mu \mathrm{m}$ nylon filter. $\mathrm{Na}^{+}$and $\mathrm{K}^{+}$were quantified with a PFP7 flame photometer (Jenway Inc., Staffordshire, UK) and $\mathrm{Cl}^{-}$with a chloride analyser.

\subsection{Osmolyte Quantification}

Three main types of osmolytes were analysed: proline (Pro), glycine betaine (GB), and total soluble sugars (TTS); in all cases, extracts were prepared from $50 \mathrm{mg}$ of dried and finely ground European larch needles. Free proline content was measured by the ninhydrin/acetic acid method [30]. Extracts were prepared in $2 \mathrm{~mL}$ of a $3 \%(w / v)$ sulfosalicylic acid solution. Each sample was mixed with acid ninhydrin, incubated for one $\mathrm{h}$ at $95^{\circ} \mathrm{C}$, cooled on ice, and extracted with toluene. The absorbance of the organic phase was determined at $520 \mathrm{~nm}$, with toluene as a blank. Pro concentration was calculated in $\mu \mathrm{mol} \mathrm{g}^{-1} \mathrm{DW}$.

Glycine betaine was analysed according to the method described by [31]. Plant samples were mixed with potassium iodide and extracted with 1,2-dichloroethane, pre-cooled at $-20^{\circ} \mathrm{C}$; the absorbance of the solution was measured at a wavelength of $365 \mathrm{~nm}$. GB concentration was expressed as $\mu \mathrm{mol} \mathrm{g}^{-1} \mathrm{DW}$.

Total soluble sugars were quantified according to the method of Dubois et al. [32]. Needle samples were mixed with three $\mathrm{mL}$ of $80 \%(v / v)$ methanol on a rocker shaker for $24 \mathrm{~h}$, and the extracts were recovered by centrifugation. After adding concentrated sulphuric acid and $5 \%$ phenol to the supernatant, the absorbance was measured at $490 \mathrm{~nm}$. TSS contents were expressed as 'mg equivalent of glucose' per gram of DW.

\subsection{Malondialdehyde (MDA) and Non-Enzymatic Antioxidants}

Methanol $(80 \% v / v)$ extracts were prepared from $50 \mathrm{mg}$ dried needles, by shaking in a rocker shaker at room temperature, for $24-48 \mathrm{~h}$. Supernatants, collected by centrifugation, were stored in a freezer at $-20{ }^{\circ} \mathrm{C}$. MDA was quantified following the method described by Hodges et al. [33]: each sample was mixed with $0.5 \%$ thiobarbituric acid (TBA) prepared in $20 \%$ trichloroacetic acid (TCA)—or with $20 \%$ TCA without TBA for the controls-and then incubated at $95^{\circ} \mathrm{C}$ for $20 \mathrm{~min}$. After cooling the samples on ice and a centrifugation step, the absorbance of the supernatants was measured at $532 \mathrm{~nm}$. The non-specific absorbance at 600 and $440 \mathrm{~nm}$ was subtracted, and the MDA concentration determined using the equations from Hodges et al. [33].

Total phenolic compounds (TPC) were analysed using the protocol by Blainski et al. [34], based on the reaction with the Folin-Ciocalteu reagent. Samples were mixed with the reagent and sodium bicarbonate and left in the dark for $90 \mathrm{~min}$. The absorbance was recorded at $765 \mathrm{~nm}$, using gallic acid (GA) as the standard. TPC concentrations were expressed as GA equivalents (mg eq. GA g ${ }^{-1} \mathrm{DW}$ ). 
Total flavonoids (TF) were determined in the same extracts by reaction with $\mathrm{NaNO}_{2}$ followed by $\mathrm{AlCl}_{3}$ in the presence of $\mathrm{NaOH}$. The absorbance was read at $510 \mathrm{~nm}$ using catechin as the standard. TF concentration was expressed as equivalents of catechin (mg eq. $\mathrm{C} \mathrm{g}^{-1} \mathrm{DW}$ ). Although this method is generally described as a procedure to measure 'total flavonoids' in the sample, in fact, it only detects aromatic rings bearing a catechol group; this group is present in several flavonoid subclasses, such as flavonols and flavanols, but also in other phenolics, for example, caffeic acid and derivatives; all these phenolics possess the common property of being strong antioxidants [35]. To simplify, we refer to the $\mathrm{AlCl}_{3}$-reactive compounds as 'total flavonoids' (TF) or 'antioxidant flavonoids'.

\subsection{Antioxidant Enzyme Activities}

The specific activity of four antioxidant enzymes was determined in European larch needles extracts: superoxide dismutase (SOD), catalase (CAT), ascorbate peroxidase (APX), and glutathione reductase (GR). Activities were measured in crude protein extracts prepared from $2 \mathrm{~g}$ of fresh needles, as indicated by Gil et al. [36]. Samples were ground in liquid $\mathrm{N}_{2}$ and proteins were extracted with $10-20 \mathrm{~mL}$ of a suitable extraction buffer of a relatively low ionic strength $[20 \mathrm{mM}$ Hepes, $\mathrm{pH}=7.5$, $50 \mathrm{mM} \mathrm{KCl}, 1 \mathrm{mM}$ EDTA, $0.1 \%(v / v)$ Triton X-100, $0.2 \%(w / v)$ polyvinylpyrrolidone, $0.2 \%(w / v)$ polyvinylpolypyrrolidone and $5 \%(v / v)$ glycerol]; then, to improve protein extraction, a $1 / 10$ volume of 'high salt buffer' (225 mM Hepes, pH 7.5, $1.5 \mathrm{M} \mathrm{KCl}$ and $22.5 \mathrm{mM} \mathrm{MgCl}_{2}$ ) was added to the samples, which were mixed and kept on ice for $5 \mathrm{~min}$. Homogenates were centrifuged at 20,000 $\mathrm{g}$ for $20 \mathrm{~min}$ at $4{ }^{\circ} \mathrm{C}$, the supernatants were concentrated in U-Tube concentrators (Novagen, Madison, WI, USA) and centrifuged again to remove the precipitated material. The protein extracts were divided into aliquots, frozen in liquid $\mathrm{N}_{2}$, and stored at $-75{ }^{\circ} \mathrm{C}$. Protein concentration in the extracts was determined by the method of Bradford [37], using the Bio-Rad reagent and bovine serum albumin as a standard. Enzyme activities in the extracts were expressed as 'specific activities', in units per mg of protein.

SOD activity in the protein extracts was determined as described by Beyer and Fridovich [38], following the inhibition of nitroblue tetrazolium (NBT) photoreduction by measuring the absorbance of the sample at $560 \mathrm{~nm}$; the reaction mixtures contained riboflavin as the source of superoxide radicals. One SOD unit was defined as the amount of enzyme causing 50\% inhibition of NBT photoreduction under the assay conditions.

CAT activity was measured by the decrease in absorbance at $240 \mathrm{~nm}$ which accompanies the consumption of $\mathrm{H}_{2} \mathrm{O}_{2}$ added to protein extracts [39]. One CAT unit was defined as the amount of enzyme that will decompose one mmol of $\mathrm{H}_{2} \mathrm{O}_{2}$ per minute at $25^{\circ} \mathrm{C}$.

APX activity was determined following the procedure described by Nakano and Asada [40], by the decrease in absorbance observed at $290 \mathrm{~nm}$ as ascorbate becomes oxidised in the reaction. One APX unit was defined as the amount of enzyme required to consume one mmol of ascorbate per minute, at $25^{\circ} \mathrm{C}$.

The protocol of [41] was used for the GR assays, following the oxidation of NADPH [the cofactor in the GR-catalysed reduction of oxidised glutathione (GSSG)] by the decrease in absorbance at $340 \mathrm{~nm}$. One GR unit was defined as the amount of enzyme that will oxidise one mmol of NADPH per minute at $25{ }^{\circ} \mathrm{C}$.

Small modifications introduced in the published assays have been previously described [36].

\subsection{Data Analysis}

Data were analysed using Statgraphics Centurion XVI (Statgraphics Technologies, The Plains, VA, USA). Before the analysis of variance, the Shapiro-Wilk test was used to check for the validity of normality assumption and Levene's test for the homogeneity of variance. If ANOVA requirements were met, significant differences among treatments were tested by one-way ANOVA at the 95\% confidence level, and post hoc comparisons were made using the Tukey HSD test. All mean values throughout the text, followed by their SE, are based on seven biological replicas. 


\section{Results}

\subsection{Substrate Analysis}

As it should be expected, the electric conductivity $\left(\mathrm{EC}_{1: 5}\right)$ of the pot substrates after one-month treatment with $150 \mathrm{mM} \mathrm{NaCl}$ was higher, about 5.5-fold, than in the non-stressed controls, whereas no significant difference was measured in the water deficit treatment (Figure 1a). On the other hand, the humidity of the substrate did not differ between the control and the salt treatment and was reduced by $\sim 50 \%$ in the pots that were not watered during the experiment (Figure $1 \mathrm{~b}$ ).

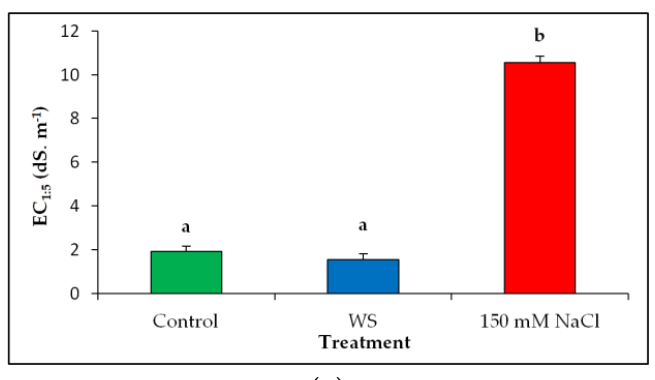

(a)

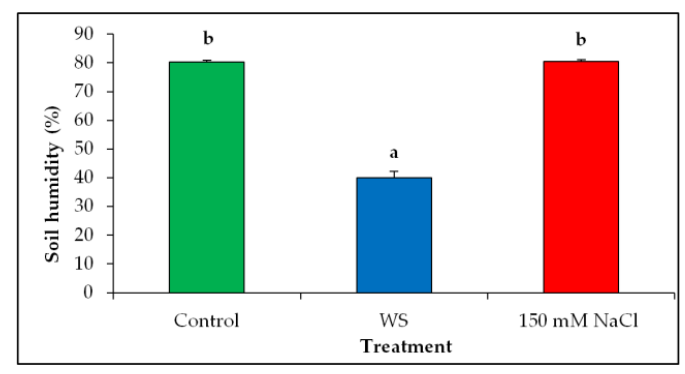

(b)

Figure 1. Substrate electric conductivity $\left(\mathrm{EC}_{1: 5}\right)(\mathbf{a})$, and humidity $(\%) ;(\mathbf{b})$ after 30 days of water deficit (WS) or salt stress $(150 \mathrm{mM} \mathrm{NaCl})$. Bars represent means with SE $(n=7)$. Different letters above the bars indicate significant differences between treatments, according to Tukey's test $(\alpha=0.05)$.

\subsection{Plant Growth Analysis}

Salt and water stress treatments inhibited the growth of European larch seedlings, as shown by the relative reduction of stem elongation and biomass accumulation in the stressed plants, compared to the controls grown under standard conditions. Significant differences in stem length elongation between control and water-stressed plants were detected after 18 days of treatment. It could be observed that stem elongation was more affected by water deficit than by salinity: from day 18 on, the average increment of stem length was higher in the non-stressed seedlings than in those grown in the presence of salt, but statistically significant differences were only observed at the end of the experiment (30 days of treatment), when stem growth of the non-irrigated plants was reduced by $37 \%$ in relation to the control, and by $26 \%$ in the case of salt-treated plants (Figure 2).

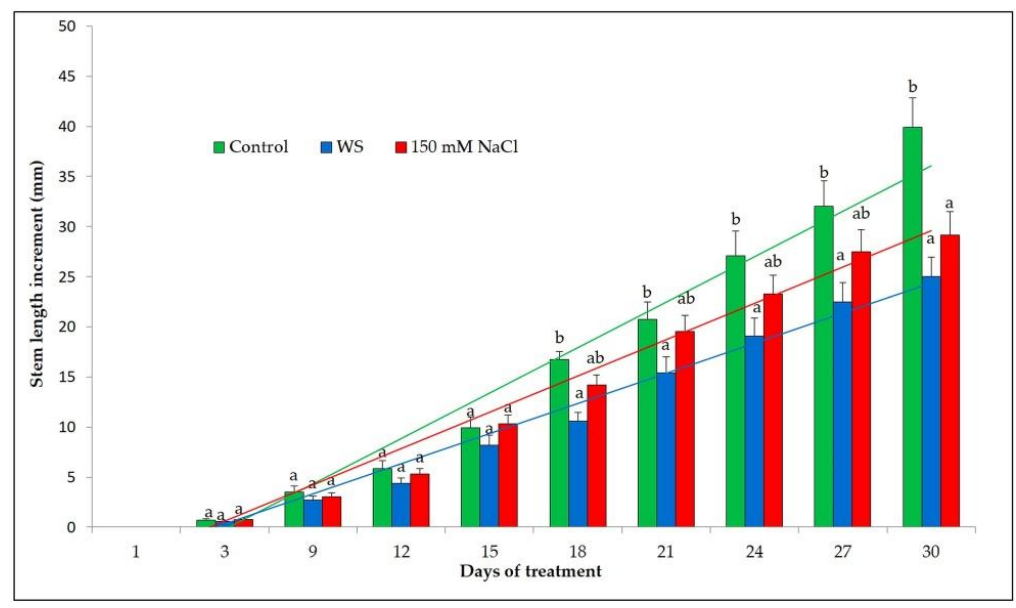

Figure 2. Effect of 30 days of water (WS) and salt $(150 \mathrm{mM} \mathrm{NaCl})$ stress treatments on stem elongation in Larix decidua. Stem length measurements were taken every three days. Bars represent means with SE $(n=7)$. Different letters above the bars indicate significant differences between treatments, according to Tukey's test $(\alpha=0.05)$. 
Whereas the reductions in stem elongation under water deficit conditions and, especially, in the presence of salt were small (Figure 2), the relative decrease of the fresh weight of the aerial part of the plants better reflected the stress-induced inhibition of growth in European larch seedlings (Figure 3). According to this parameter, no significant difference was observed between the drought and the salt treatments; average shoot fresh weight of the stressed plants was reduced by $25-30 \%$ compared to the control (Figure 3a). The water content of the needles decreased slightly (but significantly) upon both treatments, from ca. $80 \%$ in the control to $76 \%$ and $77 \%$ in the salt-stressed and the water deficit-stressed plants, respectively (Figure 3b). Therefore, at this early developmental stage, the needles appear to be relatively resistant to stress-induced dehydration, and the observed reduction of fresh weight is indeed mostly due to the inhibition of growth and not merely to the loss of water.

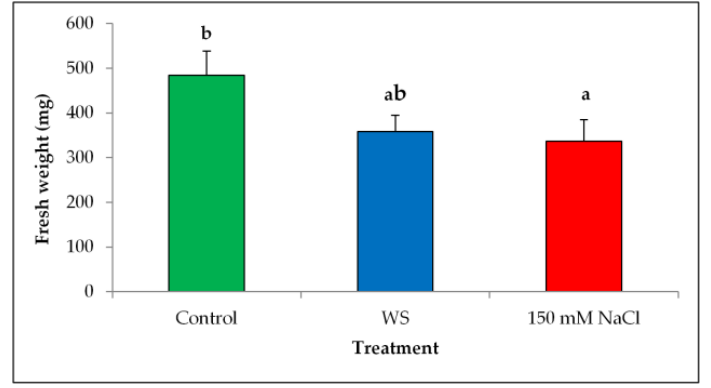

(a)

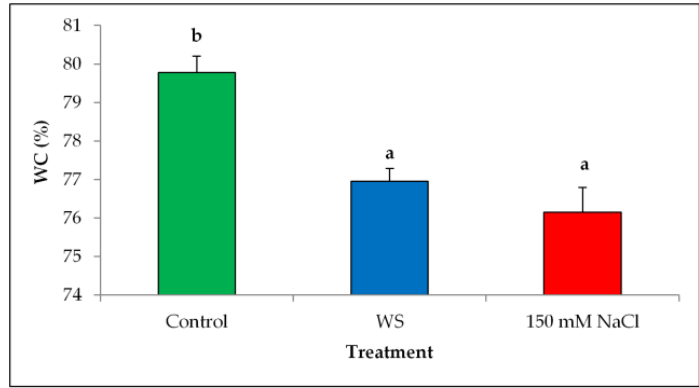

(b)

Figure 3. Stress-induced inhibition of growth. Needle fresh weight (FW) (a) and water content as a percentage of FW (WC \%) (b), in Larix decidua after 30 days of water deficit (WS) and salt (150 mM $\mathrm{NaCl})$ stress treatments. Bars represent means with $\mathrm{SE}(n=7)$. Different letters above the bars indicate significant differences between treatments, according to Tukey's test $(\alpha=0.05)$.

\subsection{Degradation of Photosynthetic Pigments}

Mean needle contents of photosynthetic pigments—chlorophylls a and $\mathrm{b}$ and carotenoids—decreased when the plants were subjected to stress, but the difference with the control, non-stressed plants was only significant in the case of salt stress, not for the European larch seedlings subjected to water deficit (Figure 4). In the presence of $150 \mathrm{mM} \mathrm{NaCl}$, the levels of chlorophylls a and $\mathrm{b}$ were reduced by $\sim 30 \%$ of the control, whereas the relative reduction of total carotenoids was somewhat smaller, with a value of $22 \%$ (Figure 4 ).

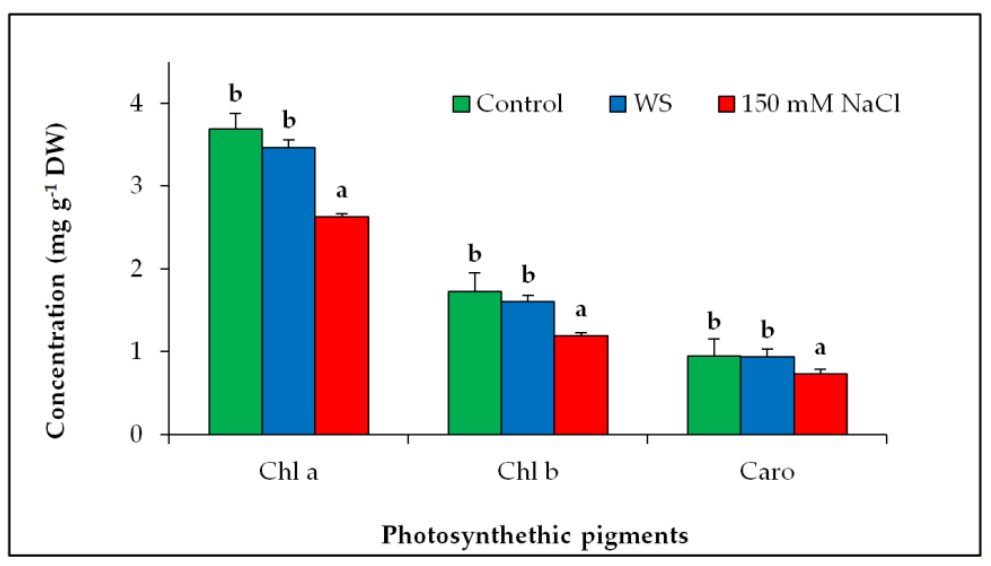

Figure 4. Degradation of photosynthetic pigments. Leaf concentrations of chlorophyll a (Chl a), chlorophyll b (Chl b), and total carotenoids (Caro), in Larix decidua seedlings after 30 days of water (WS) and salt stress $(150 \mathrm{mM} \mathrm{NaCl})$ treatments. Bars represent means with SE $(n=7)$. Different letters above the bars indicate significant differences between treatments, according to Tukey's test $(\alpha=0.05)$. 


\subsection{Monovalent Ions Levels}

Sodium $\left(\mathrm{Na}^{+}\right)$and chloride $\left(\mathrm{Cl}^{-}\right)$contents were measured in the roots and needles of L. decidua plants, once the experimental treatments were concluded. As it should be expected, no significant differences were observed in the levels of these ions between control and drought-stressed plants, neither in roots nor in needles; on the contrary, $\mathrm{Na}^{+}$and $\mathrm{Cl}^{-}$levels were much higher in salt-treated plants (Figure $5 \mathrm{a}, \mathrm{b}$ ). In the presence of $150 \mathrm{mM} \mathrm{NaCl}, \mathrm{Na}^{+}$contents were about four-fold higher than under non-stress conditions, both in roots and needles (Figure 5a). On the other hand, the salt treatment induced the accumulation of $\mathrm{Cl}^{-}$to concentrations 16-fold (roots) or nine-fold (needles) higher than in the corresponding controls (Figure $5 b$ ). When comparing $\mathrm{Na}^{+}$levels in roots and needles, no significant differences were observed in control or salt-stressed plants, whereas the $\mathrm{Na}^{+}$concentration was slightly higher ( 1.3-fold) in roots of water-stressed seedlings (Figure 5a). Measurements of $\mathrm{Cl}^{-}$contents revealed significantly higher values in needles than in roots under all tested conditions, about twofold in control plants and those subjected to the water deficit treatment, and 1.2-fold in salt-treated plants (Figure 5b).

The most remarkable change in the patterns of $\mathrm{K}^{+}$levels was that, in salt-treated plants, the cation accumulated to more than double the concentration in needles than in roots; this was due to both a significant decrease of $\mathrm{K}^{+}$in roots and a significant increase in needles, compared with the non-stressed seedlings. In control and water-stressed plants, no significant differences were observed between underground and aboveground parts (Figure 5c). As a consequence of the relative variation in $\mathrm{Na}^{+}$ and $\mathrm{K}^{+}$levels, the $\mathrm{K}^{+} / \mathrm{Na}^{+}$ratios were practically identical in non-stressed controls and after the water deficit treatment, much lower after the salt-treatment and, in all cases, somewhat higher in needles than in roots (Figure 5d).

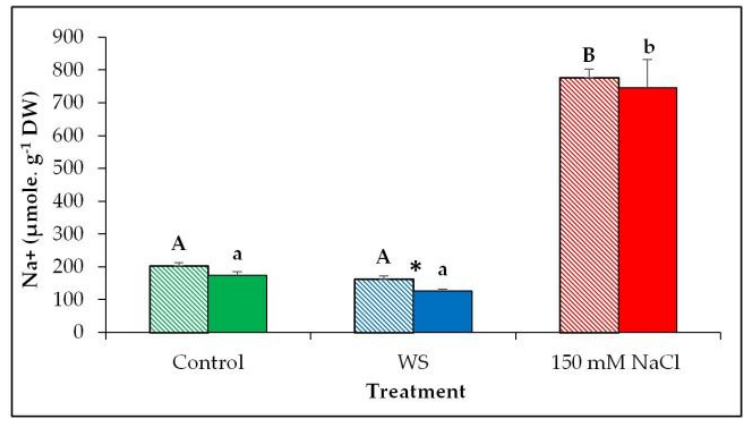

(a)

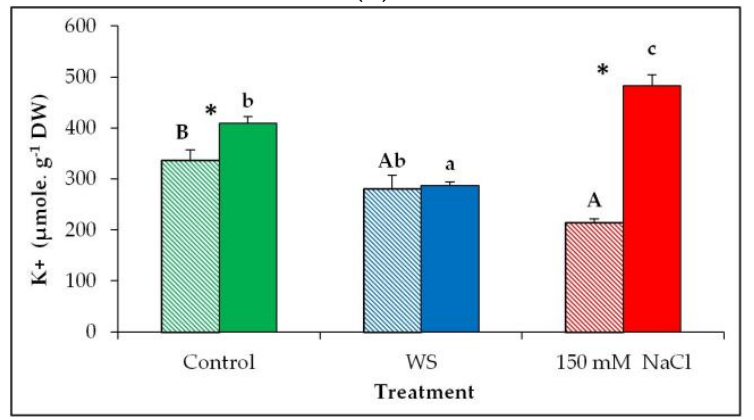

(c)

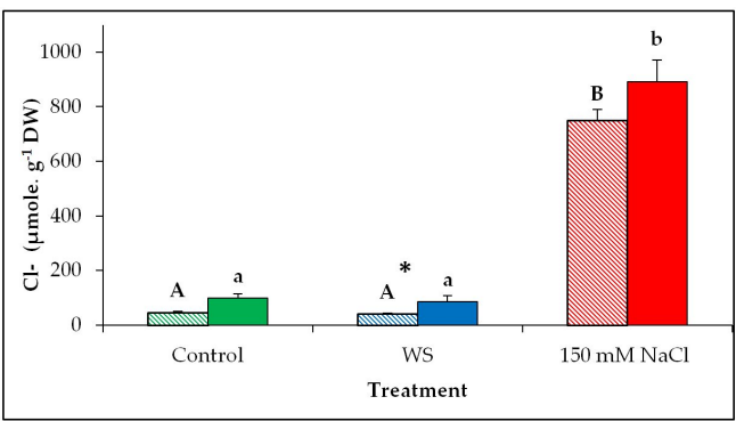

(b)

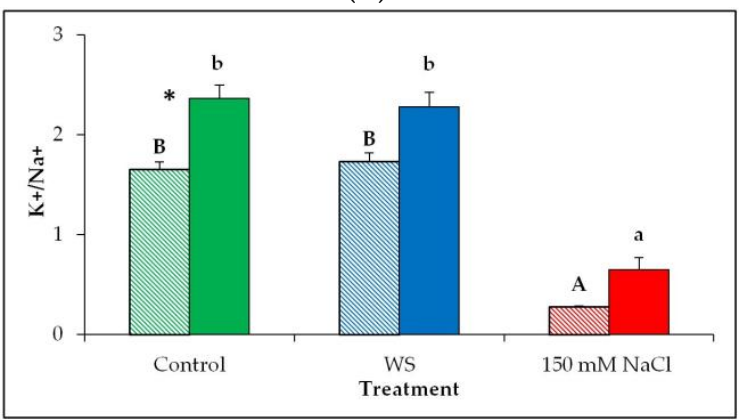

(d)

Figure 5. Monovalent ion contents in roots (striped bars) and needles (solid bars) of Larix decidua after 30 days of water (WS) and salt stress $(150 \mathrm{mM} \mathrm{NaCl})$ treatments: (a) sodium; (b) potassium; (c) chloride; (d) ratio potassium over sodium. Values shown are means \pm SE $(n=7)$. Different letters (lowercase for roots and capital for needles) above the bars indicate significant differences between treatments, and asterisks significant differences between roots and needles for the same treatment, according to Tukey's test $(\alpha=0.05)$. 


\subsection{Osmolytes Levels}

Osmolyte biosynthesis is a general response of plants—and indeed of all organisms—to environmental conditions generating osmotic stress, such as drought or salinity; accumulation of these compatible solutes helps to maintain osmotic balance, avoiding or minimising cell dehydration. We have measured the levels of the three main plant osmolytes: proline (Pro), glycine betaine (GB), and total soluble sugars (TSS), in needles of European larch seedlings after the water and salt stress treatments. Pro levels were very low (less than $10 \mu \mathrm{mol} \mathrm{g}{ }^{-1} \mathrm{DW}$ ) in control, non-stressed plants, and did not vary significantly in seedlings subjected for one month to water deficit conditions; however, they increased about three-fold in those grown in the presence of $150 \mathrm{mM} \mathrm{NaCl}$ (Figure 6a). Needle GB contents were much higher than those of Pro, $\sim 200 \mu \mathrm{mol} \mathrm{g}^{-1} \mathrm{DW}$ in control seedlings, and did not show any significant variation under any of the stress conditions tested, salt stress or withholding watering of the plants (Figure 6b). Finally, mean TSS levels were about $75 \mathrm{mg}$ eq. glucose $\mathrm{g}^{-1} \mathrm{DW}$ and increased slightly (but significantly), ca. 1.2-fold, under water deficit and salinity conditions (Figure 6c).

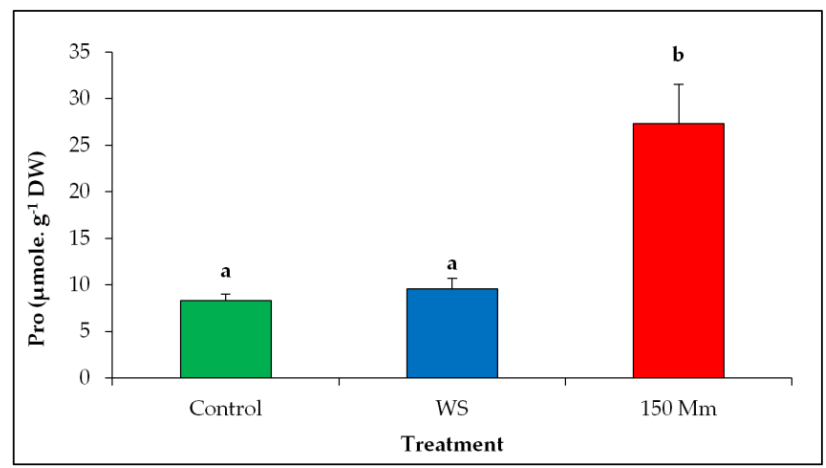

(a)

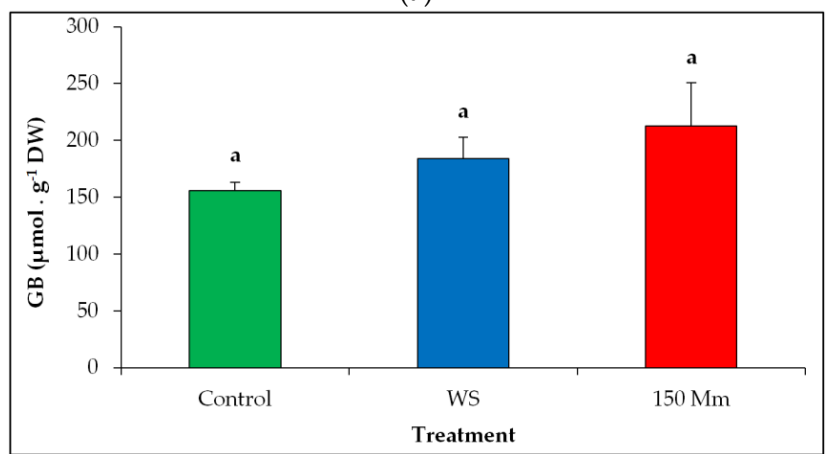

(b)

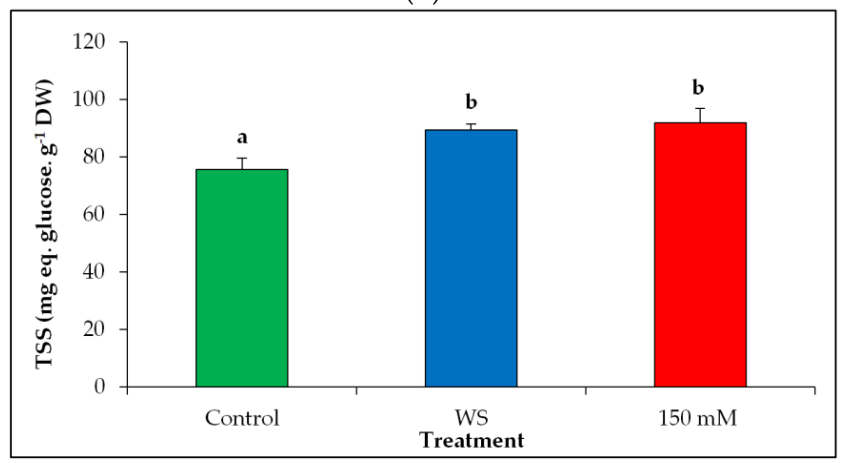

(c)

Figure 6. Needle contents of (a) proline (Pro); (b) glycine betaine (GB); and (c) total soluble sugars (TSS), in Larix decidua seedlings after days of water and salt treatments. Values shown are means \pm SE $(n=7)$. Different letters above the bars indicate significant differences between treatments, according to Tukey's test $(\alpha=0.05)$. 


\subsection{Oxidative Stress}

The concentrations of malondialdehyde (MDA), a reliable biomarker of oxidative stress, were determined to assess the oxidative damage suffered by European larch seedlings under water deficit and salt stress conditions. As shown in Table 1, both treatments induced a significant, although small (1.2- to 1.3-fold), increase in the MDA contents of the plant needles. No change in the levels of the tested groups of non-enzymatic antioxidants, TPC and TF, was observed in the same samples (Table 1).

Table 1. Oxidative stress and antioxidant responses in Larix decidua. Malondialdehyde (MDA), total phenolic compounds (TPC), total flavonoids (TF) levels, and superoxide dismutase (SOD), catalase (CAT), ascorbate peroxidase (APX), and glutathione reductase (GR) specific activities, in methanol extracts (MDA, TPC, TF) or protein extracts (enzymes) of needles of Larix decidua seedlings after 30 days of water deficit (WS) and salt stress (150 $\mathrm{mM} \mathrm{NaCl})$ treatments ${ }^{1}$.

\begin{tabular}{|c|c|c|c|}
\hline Biochemical Parameter & Control & WS & $150 \mathrm{mM} \mathrm{NaCl}$ \\
\hline MDA (nmol g $\left.{ }^{-1} \mathrm{DW}\right)$ & $205.50 \pm 10.68 \mathrm{a}$ & $259.13 \pm 6.39 \mathrm{~b}$ & $284.06 \pm 11.70 \mathrm{~b}$ \\
\hline $\mathrm{TPC}$ (mg eq. $\left.\mathrm{GA} \mathrm{g}^{-1} \mathrm{DW}\right)$ & $4.29 \pm 0.25 \mathrm{ab}$ & $4.55 \pm 0.15 \mathrm{~b}$ & $3.84 \pm 0.13 a$ \\
\hline $\mathrm{TF}$ (mg eq. $\left.\mathrm{Cg}^{-1} \mathrm{DW}\right)$ & $3.18 \pm 0.36 \mathrm{a}$ & $3.54 \pm 0.27 \mathrm{a}$ & $3.16 \pm 0.31 \mathrm{a}$ \\
\hline $\mathrm{SOD}$ (U mg ${ }^{-1}$ protein) & $56.72 \pm 4.87 \mathrm{a}$ & $81.59 \pm 5.68 b$ & $131.81 \pm 13.92 \mathrm{c}$ \\
\hline CAT (U mg ${ }^{-1}$ protein) & $32.32 \pm 5.15 \mathrm{a}$ & $43.03 \pm 3.95 b$ & $87,27 \pm 6.24 c$ \\
\hline APX (U mg ${ }^{-1}$ protein $)$ & $918.50 \pm 96.18 a$ & $2419.61 \pm 282.58 b$ & $3521.70 \pm 225.17 \mathrm{c}$ \\
\hline GR (U mg ${ }^{-1}$ protein) & $45.64 \pm 3.61 \mathrm{a}$ & $59.86 \pm 6.68 b$ & $86.34 \pm 4.63 c$ \\
\hline
\end{tabular}

\footnotetext{
${ }^{1}$ Values shown are means \pm SE $(n=7)$. Different letters in each row indicate significant differences between treatments, according to Tukey's test $(\alpha=0.05)$.
}

The specific activities of some of the most important antioxidant enzymatic systems-namely SOD, CAT, APX, and GR - were calculated in crude protein extracts prepared from the needles of control and stressed seedlings. As compared to the non-stressed plants, water deficit and salt treatments caused significant increases in the activity of the four enzymes, to a variable degree-from 1.3-fold to 3.8-fold, depending on the enzyme and the treatment. Under the experimental conditions used, the salt treatment had a stronger effect than water stress regarding the activation of the antioxidant enzymes (Table 1).

\section{Discussion}

\subsection{Seedling Growth and Photosynthetic Pigments}

Reduction of growth is probably the most general response of plants upon exposure to any kind of stress, and it has been reported, for instance, in practically all studies dealing with the effects of salinity or drought. Growth inhibition is due to the reallocation of plant resources towards the activation of defence mechanisms, instead of biomass accumulation [42,43]. Measurement of morphological parameters to estimate the degree of stress-induced growth inhibition is, therefore, the most straightforward and convenient approach to quantitatively assess the effect on plants of abiotic stress conditions, including water deficit or high soil salinity. In species of very slow growth, such as conifers and many other woody species, lengthy treatments are required to detect the effects of the applied stress [27]. However, among Pinaceae, Larix decidua is considered as a fast-growing tree [7]. In agreement with this idea, in our experiments, one-month treatments were sufficient to detect significant reductions of stem elongation and, especially, of biomass accumulation in stressed seedlings, as compared to the non-stressed controls. The use of appropriate stress conditions, $150 \mathrm{mM}$ $\mathrm{NaCl}$ and complete withholding of irrigation for 30 days, allowed detecting significant changes on growth parameters-and on the levels of different biochemical stress markers-without being lethal for the plants.

The relative reduction of fresh weight was, indeed, mostly due to growth inhibition and not to the loss of water caused by drought or salt stress, since the decrease of needle water content was 
limited to $\sim 5 \%$, without significant differences between the two stress treatments. In our experimental conditions, therefore, L. decidua appears to be quite resistant to dehydration. In a previous study, based on calculations of sap flux and xylem water potential on a tree line in the Alps, Baladotti et al. [44] concluded that European larch can accumulate compatible solutes that allow maintaining a high stomatal conductance at low water potential, so that the species is less sensitive to soil water shortage than other conifers. On the contrary, other reports showed the vulnerability of European larch to drought in its natural stands [45,46] or in afforestation sites [47], which can be explained by the species' deciduous habit and high rate of transpiration even under drought, affecting the tree water status [48]. Since we applied a relatively short treatment of water deficit, of only 30 days, its observed effects at the morphological level cannot be directly compared to the behaviour of the species in nature. In addition, even under controlled greenhouse conditions, tolerance to drought may vary between populations of the same species with a different origin, as has been reported in spruce [49]. Regarding responses to salinity, to our knowledge, there are no reports published on L. decidua and few on other species of the genus. For example, L. laricina, commonly known as tamarack or American larch, native to Canada, was also found to be sensitive to $\mathrm{NaCl}$ treatments, showing similar responses to those observed in our experiments with European larch, but at much lower concentrations (30-60 mM) [50].

A reduction in the leaf contents of photosynthetic pigments is also a general response to abiotic stresses, resulting from a combination of factors: the reduction of chlorophyll synthesis, the activation of its degradation by chlorophyllase, and the inhibition of primary enzymes involved in photosynthesis such as Rubisco and PEP carboxylase [51]. A decrease in chlorophylls a and b, and in total carotenoids as well, has been reported in different coniferous species subjected to salt and drought treatments [27,52-54]. We have also detected a reduction in the mean values of the needle contents of these pigments, but the differences with the control were only statistically significant for the salt stress treatment, indicating that under the experimental conditions used, European larch is more sensitive to salinity than to drought.

\subsection{Ion Homeostasis}

It is not to be expected that water stress could change the endogenous ion contents of the affected plants and, accordingly, the levels of $\mathrm{Na}^{+}, \mathrm{Cl}^{-}$, and $\mathrm{K}^{+}$did not vary significantly, in general, in L. decidua seedlings after the drought treatment, as compared to the non-stressed controls. On the contrary, the regulation of ion transport is especially relevant in the responses of plants to salt stress. A common strategy to respond to salt stress among glycophytes, which include all major crops, is to maintain low $\mathrm{Na}^{+}$concentrations in the leaves, either by exclusion mechanisms at the root level, or by blocking its transport to the leaves; therefore, in these species, salt tolerance results from limitation of the uptake of toxic ions and their storage at the root or stem level [9,55-58]. On the other hand, halophytes, especially dicotyledonous succulent species, generally accumulate high concentrations of $\mathrm{Na}^{+}$in their leaves, although sequestered in the vacuoles to avoid its toxic effects in the cytoplasm $[17,42]$. Nevertheless, in (relatively) salt-resistant genotypes of some crop species, $\mathrm{Na}^{+}$compartmentalisation in leaf vacuoles may also contribute to salinity tolerance [59]. Salinity caused the accumulation of high concentrations of $\mathrm{Na}^{+}$and $\mathrm{Cl}^{-}$in L. decidua roots and needles, as reported for other coniferous species $[27,60,61]$. When comparing ion levels between roots and needles, no differences were observed in $\mathrm{Na}^{+}$contents (in terms of DW), neither in control nor in salt-stressed seedlings; regarding $\mathrm{Cl}^{-}$, its concentration was slightly (but significantly) higher in needles than in roots, again in both non-stressed and salt-stressed seedlings. These results indicate that European larch responses to salinity do not include mechanisms blocking the transport of toxic ions from underground to aboveground parts of the plants, contrary to what has been described for most glycophytic taxa, including many crops $[57,62]$, or for halophytic monocotyledonous species [63].

An unusual pattern of salt-induced variation was established for $\mathrm{K}^{+}$concentrations. $\mathrm{Na}^{+}$accumulation is generally accompanied by a reduction of $\mathrm{K}^{+}$levels, as the two ions compete for the same transport systems $[64,65]$. A significant reduction of $\mathrm{K}^{+}$content was indeed detected in 
the roots of salt-treated European larch seedlings, but just the opposite was observed in the needles, which accumulated significantly higher levels of the cation than in the absence of external $\mathrm{NaCl}$. This result strongly suggests that high soil salinity activates $\mathrm{K}^{+}$transport from roots to shoots, to maintain relatively high leaf concentrations of this physiological cation. Avoiding an excessive reduction of cytoplasmic $\mathrm{K}^{+} / \mathrm{Na}^{+}$ratios appears to be a general mechanism of defence against high salinity; determination of ion levels in specific subcellular compartments is, however, technically difficult, and it has been recently considered that measurements of salt-induced changes in total leaf $\mathrm{K}^{+}$ concentrations represent a more a parsimonious approach to assess plant responses to salt stress $[42,66]$. The maintenance or even increase of $\mathrm{K}^{+}$levels in plants under salt stress conditions has been reported in many crops, including the classical study by Läuchli and Wieneke in soybean [67].

Similar behaviour has been reported in Larix laricina [50] and Picea abies [27], highlighting the importance of maintaining relatively high $\mathrm{K}^{+}$concentrations in the needles, as a mechanism to withstand, to a certain degree, the deleterious effects of salt stress in trees of the Pinaceae family.

\subsection{Osmolyte Synthesis}

Adverse environmental conditions, such as soil salinity, drought, and cold or high temperatures, cause osmotic stress in plants. A general response to these abiotic stress factors is based, accordingly, on the synthesis and cytoplasmic accumulation of compatible solutes or 'osmolytes', compounds of a diverse chemical nature that do not interfere with cellular metabolism, even at high concentrations, and help to avoid cell dehydration and to maintain osmotic balance under stress [11]. Proline is one of the most typical compatible solutes in plants [68] and it has been reported to significantly increase in many plant species, including conifers, under different abiotic stress conditions. For example, drought or salinity treatments have been shown to cause Pro accumulation in pine species [69-71], or in spruce $[27,49,72]$. In one-month-old plantlets of Larix $\times$ eurolepis Henry (Larix decidua $\times$ Larix kaempferi) grown in the presence of cadmium, Pro contents were reported to increase about three-fold over control values [73], similarly to what we have detected in the present study in salt-treated European larch seedlings. Moreover, embryogenic tissue of transgenic hybrid larch Larix leptoeuropaea containing high Pro levels-by overexpression of the pyrroline 5-carboxylate synthase gene from Vigna aconitifolia -was found to be more resistant than the non-transformed controls to high salinity, as well as to other abiotic stresses, such as cold or frost [74]. Nevertheless, Pro concentration in L. decidua, even in salt-treated seedlings, was too low to have any significant osmotic effect. Therefore, a putative role of Pro in the responses to salt stress in European larch would be based on its 'osmoprotectant' functions, as a low-molecular-weight chaperon, ROS scavenger, or as a signalling molecule [21]. It is also noteworthy that seedlings exposed to water deficit did not show any increase in Pro contents, supporting the notion that this osmolyte is not involved in the mechanisms of drought tolerance in L. decidua. Glycine betaine is also a common osmolyte in many plant species, where it is synthesised in response to drought and high salinity stress [75]. To our knowledge, GB levels have not been previously reported in European larch. Needle concentrations of GB, $200 \mu \mathrm{mol} \mathrm{g}^{-1} \mathrm{DW}$, were high enough to exert a significant osmotic effect, suggesting an essential role in osmotic adjustment under stress in L. decidua. Yet GB contents did not differ significantly between control and stressed plants, as it has been reported in several halophytes that are typical GB accumulators. They include, for example, Suaeda fruticosa [76], Salicornia dolichostachya [77], or Inula chritmoides [78]. Also, field studies revealed only small fluctuations in GB contents in response to drastic changes in environmental conditions (i.e., in soil humidity and salinity) in some halophytes that use GB as the functional osmolyte [36]. These data suggest the existence of constitutive mechanisms of tolerance in plants adapted to stressful environments, based on changes in the intracellular location of specific osmolytes rather than on their de novo synthesis [79], and similar mechanisms could also operate in L. decidua.

Soluble sugars also constitute essential functional osmolytes for many plants, and their accumulation in response to drought has been reported in the needles, sapwood, and inner bark of coniferous species [80]. In the present study, only a small increase in TSS levels was detected in 
water and salt-stressed L. decidua seedlings, whereas a decrease in response to $60 \mathrm{mM} \mathrm{NaCl}$ has been reported for L. laricina [50]. Also, isotope techniques were used to determine variation in sugar contents in needles and phloem of L. gmelinii, to assess, in correlation with tree ring analysis, the effects of global warming on Siberian forests, but this work did not consider their role as osmolytes [81]. In any case, it is always difficult to establish the specific functional role of soluble sugars as osmolytes in the responses to stress, due to their multiple roles in plants as metabolic precursors, energy sources, or signalling molecules [82].

\subsection{Oxidative Stress and Antioxidant Mechanisms}

MDA is a reactive aldehyde generated by the ROS-induced oxidation of membrane lipids and is used as a suitable biomarker of cellular oxidative stress [83]. In European larch seedlings, both water deficit and salt stress appear to cause a certain degree of oxidative stress, reflected in small (1.3- to 1.4-fold) but statistically significant increases in MDA concentrations over the non-stressed control. Nevertheless, this increment is smaller than that observed in other glycophytes subjected to similar stress treatments, for example, Juncus articulatus [84], Nerium oleander [85], or sorghum, a moderately salt resistant crop [86].

In plants, the primary ROS-scavenging pathway is the ascorbate-glutathione cycle (AsA-GSH), which consists of the successive oxidation and reduction of ascorbate, glutathione, and NADPH, catalysed by several enzymes [87]. Superoxide dismutases (SOD) are frontline enzymes in ROS scavenging by catalysing the dismutation of the superoxide radical $\left(\mathrm{O}_{2}{ }^{\bullet-}\right)$ to $\mathrm{H}_{2} \mathrm{O}_{2}$. Catalases (CAT) and ascorbate peroxidases (APX) are responsible for reducing $\mathrm{H}_{2} \mathrm{O}_{2}$ to $\mathrm{H}_{2} \mathrm{O}$, the latter using ascorbate as the specific electron donor. Glutathione reductase (GR) is also a key enzyme of the AsA-GSH cycle, using NADPH as a cofactor to catalyse the reduction of oxidized glutathione (GSSG) to reduced glutathione (GSH) [88]. Although other oxidoreductases may contribute to maintaining cellular redox equilibrium, determination of the activities of these four enzymes provides a reliable assessment of the activation of antioxidant systems in response to the oxidative stress generated by drought, salinity, or other abiotic stresses. Indeed, an increase in the specific activities of all assayed enzymes-SOD, CAT, APX, and GR-has been detected in European larch seedlings subjected to water deficit or salt treatments, in all four cases higher in the presence of $\mathrm{NaCl}$ than by lack of irrigation. These findings indicate once more that water stress was less damaging to plants than salt stress, under our experimental conditions, and that L. decidua possesses antioxidant enzymatic equipment efficient in ROS scavenging. Fini et al. [89] stated that that the antioxidant enzymes represent 'the first line of defence against ROS' and only when their activity declines under severe stress is the biosynthesis of secondary ROS scavenging systems (including antioxidant phenolics and flavonoids) triggered. In the present study, it seems clear that activation of the antioxidant enzymes is sufficient to counteract the weak generation of oxidative stress under water deficit or salt stress conditions, thus explaining the lack of significant increases in the levels of the tested non-enzymatic antioxidants. Further studies will be required to confirm and extend the results presented here, regarding the larch defence mechanisms against drought and salinity based on the activation of antioxidant systems. They could include measurements of stress-induced changes in the levels of additional non-enzymatic antioxidants and intermediates in the AsA-GSH cycle-such as vitamin E, carotenoids, $\mathrm{H}_{2} \mathrm{O}_{2}$, ascorbate, GSH, or the ratio GSH/GSSG - as well as in the specific activities of additional antioxidant enzymes. Moreover, a combination of the two types of stress, by providing salt before water limitation-or vice versa - to the plants, would represent an interesting strategy to deepen our understanding of the mechanisms of response to stress in this species. Although not likely in their natural habitats, European larch could face the two types of stress in a short succession if used as ornamental trees, when they are watered with low-quality irrigation water, with a high content of salts, during the hot season. 


\section{Conclusions}

The present study presents new experimental data on Larix decidua, an important coniferous species for which very little information is available about its responses to water deficit and salinity stress. European larch seedlings were affected by both stresses, as indicated by the inhibition of growth and degradation of photosynthetic pigments, as well as the increase of $\mathrm{Na}^{+}$and $\mathrm{Cl}^{-}$concentrations in their shoots, which represent typical responses to abiotic stress (the latter specific to salinity only). Plants can activate different mechanisms of defence to cope with these stresses; in the case of European larch, our results indicate that the most relevant of such mechanisms appear to depend on the constitutive accumulation of relatively high concentrations of glycine betaine to maintain cellular osmotic balance, and on the activation of antioxidant enzymes. Additional mechanisms, specific for the defence against salt stress, include the activation of $\mathrm{K}^{+}$transport from roots to shoots, and the accumulation of Pro as an osmoprotectant. These results are relevant for understanding the responses of European larch to drought and salinity and may help to carry out conservation and reforestation programmes for this species, designed considering climate change effects, and also facilitate its use as an ornamental tree in gardens, parks, and other urban areas.

Author Contributions: R.E.S. and M.B. conceived and designed the experiments; I.M.P., S.G.-O., and M.A.H. performed the experiments; A.F.S. and J.P. analysed the data; A.F.S. and O.V. contributed reagents and materials; O.V., J.P., R.E.S., and M.B. wrote the paper.

Acknowledgments: I.M.P. and M.A.H. were recipients of Erasmus Mundus pre-doctoral scholarships financed by the European Commission.

Conflicts of Interest: The authors declare no conflict of interest.

\section{References}

1. Koskela, J.; Buck, A.; du Cros, E.T. EUFORGEN Climate Change and Forest Genetic Diversity: Implications for Sustainable Forest Management in Europe; Biodiversity International: Rome, Italy, 2007; Available online: http:/ / www.euforgen.org/fileadmin/bioversity/publications/pdfs/1216 (accessed on 15 November 2017).

2. Lindner, M.; Maroschek, M.; Netherer, S.; Kremer, A.; Barbati, A.; Garcia-Gonzalo, J.; Seidl, R.; Delzon, S.; Corona, P.; Kolström, M.; Lexer, M.J. Climate change impacts, adaptive capacity, and vulnerability of European forest ecosystems. For. Ecol. Manag. 2010, 259, 698-709. [CrossRef]

3. Bartels, D.; Sunkar, R. Drought and salt tolerance in plants. Crit. Rev. Plant Sci. 2005, 24, 23-58. [CrossRef]

4. Savolainen, O.; Bokma, F.; Knürr, T.; Kärkkäinen, K.; Pyhäjärvi, T.; Wachowiak, W. Adaptation of forest trees to climate change. In Proceedings of the Climate Change and Forest Genetic Diversity: Implications for Sustainable Forest Management in Europe, Paris, France, 15-16 March 2006; Biodiversity International: Rome, Italy, 2007; pp. 19-29. Available online: http://www.bioversityinternational.org/publications/Pdf/1216.pdf (accessed on 15 November 2017).

5. Vilcan, A.; Mihalte, L.; Sestras, A.F.; Holonec, L.; Sestras, R.E. Genetic variation and potential genetic resources of several Romanian larch populations. Turk. J. Agric. For. 2017, 41, 82-91. [CrossRef]

6. Masson, G. Autécologie des Essences Forestières; Editions TEC \& DOC; Lavoisier: Paris, France, 2005; Volume 2, pp. 141-156.

7. Matras, J.; Pâques, L. EUFORGEN Technical Guidelines for Genetic Conservation and Use for European Larch (Larix decidua); Biodiversity International: Rome, Italy, 2008; p. 6.

8. Larcher, W. Physiological Plant Ecology; Springer: Berlin, Germany, 2003.

9. Mbarki, S.; Sytar, O.; Cerda, A.; Zivcak, M.; Rastogi, A.; He, X.; Zoghlami, A.; Abdelly, C.; Brestic, M. Strategies to mitigate the salt stress effects on photosynthetic apparatus and productivity of crop plants. In Salinity Responses and Tolerance in Plants, Volume 1. Targeting Sensory, Transport and Signaling Mechanisms; Kumar, V., Wani, S.H., Suprasanna, P., Tran, L.-S.P., Eds.; Springer International Publishing AG: Cham, Switzerland, 2018; pp. 85-136.

10. Sun, Z.W.; Ren, L.K.; Fan, J.W.; Li, Q.; Wang, K.J.; Guo, M.M.; Wang, L.; Li, J.; Zhang, G.X.; Yang, Z.Y.; et al. Salt response of photosynthetic electron transport system in wheat cultivars with contrasting tolerance. Plant Soil Environ. 2016, 62, 515-521. [CrossRef] 
11. Zhu, J.-K. Abiotic stress signaling and responses in plants. Cell 2016, 167, 313-324. [CrossRef] [PubMed]

12. Lugo-Cruz, E.; Zavala-García, F.; Picón-Rubio, F.; Urías-Orona, V.; Rodríguez-Fuentes, H.; Vidales-Contreras, J.; Carranza-De La Rosa, R.; Niño-Medina, G. Water stress effect on cell wall components of maize (Zea mays) Bran. Not. Sci. Biol. 2016, 8, 81-84. [CrossRef]

13. Battaglia, M.; Olvera-Carrillo, Y.; Garciarrubio, A.; Campos, F.; Covarrubias, A.A. The enigmatic LEA proteins and other hydrophilins. Plant Physiol. 2008, 148, 6-24. [CrossRef] [PubMed]

14. Fita, A.; Rodríguez-Burruezo, A.; Boscaiu, M.; Prohens, J.; Vicente, O. Breeding and domesticating crops adapted to drought and salinity: a new paradigm for increasing food production. Front. Plant Sci. 2015, 6, 978. [CrossRef] [PubMed]

15. Zhang, D.; Tong, J.; He, X.; Xu, Z.; Xu, L.; Wei, P.; Huang, Y.; Brestic, M.; Ma, H.; Shao, H. A novel soybean intrinsic protein gene, GmTIP2;3, involved in responding to osmotic stress. Front. Plant Sci. 2016, 6, 1237. [CrossRef] [PubMed]

16. Fardus, J.; Matin, M.; Hasanuzzaman, M.; Hossain, M.; Nath, S.; Hossain, M.; Rohman, M.; Hasanuzzaman, M. Exogenous salicylic acid-mediated physiological responses and improvement in yield by modulating antioxidant defense system of wheat under salinity. Not. Sci. Biol. 2017, 9, 219-232. [CrossRef]

17. Flowers, T.J.; Colmer, T.D. Salinity tolerance in halophytes. New Phytol. 2008, 179, 945-963. [CrossRef] [PubMed]

18. Griffith, M.; Yaish, M.W.F. Antifreeze proteins in overwintering plants: A tale of two activities. Trends Plant Sci. 2004, 9, 399-405. [CrossRef] [PubMed]

19. Chen, T.H.H.; Murata, N. Glycinebetaine: an effective protectant against abiotic stress in plants. Trends Plant Sci. 2008, 13, 499-505. [CrossRef] [PubMed]

20. Hussain, T.M.; Chandrasekhar, T.; Hazara, M.; Sultan, Z.; Saleh, B.K.; Gopal, G.R. Recent advances in salt stress biology-A review. Biotechnol. Mol. Biol. Rev. 2008, 3, 8-13.

21. Szabados, L.; Savouré, A. Proline: A multifunctional amino acid. Trends Plant Sci. 2010, 15, 89-97. [CrossRef] [PubMed]

22. Apel, K.; Hirt, H. Reactive oxygen species: metabolism, oxidative stress, and signal transduction. Annu. Rev. Plant Biol. 2004, 55, 373-399. [CrossRef] [PubMed]

23. Miller, G.; Shulaev, V.; Mittler, R. Reactive oxygen signaling and abiotic stress. Physiol. Plant. 2008, 133, 481-489. [CrossRef] [PubMed]

24. Yan, K.; Shao, H.; Shao, C.; Chen, P.; Zhao, S.; Brestic, M.; Chen, X. Physiological adaptive mechanisms of plants grown in saline soil and implications for sustainable saline agriculture in coastal zone. Acta Physiol. Plant. 2013, 35, 2867-2878. [CrossRef]

25. Esfandiari, E.; Gohari, G. Response of ROS-scavenging systems to salinity stress in two different wheat (Triticum aestivum L.) cultivars. Not. Bot. Horti Agrobo. 2017, 45, 287-291. [CrossRef]

26. Hoagland, D.R.; Arnon, D.I. The Water-Culture Method for Growing Plants without Soil; California Agricultural Experiment Station Publications Series; College of Agriculture, University of California: Davis, CA, USA, 1950.

27. Shiop, S.T.; Al Hassan, M.; Sestras, A.F.; Boscaiu, M.; Sestras, R.E.; Vicente, O. Identification of salt stress biomarkers in Romanian Carpathian populations of Picea abies (L.) Karst. PLoS ONE 2015, 10, e0135419. [CrossRef] [PubMed]

28. Lichenthaler, H.K.; Wellburn, A.R. Determinations of total carotenoids and chlorophylls a and b of leaf extracts in different solvents. Biochem. Soc. Trans. 1983, 11, 591-592. [CrossRef]

29. Weimberg, R. Solute adjustments in leaves of two species of wheat at two different stages of growth in response to salinity. Physiol. Plant. 1987, 70, 381-388. [CrossRef]

30. Bates, L.S.; Waldren, R.P.; Teare, I.D. Rapid determination of free proline for water stress studies. Plant Soil 1973, 39, 205-207. [CrossRef]

31. Grieve, C.M.; Grattan, S.R. Rapid assay for determination of water soluble quaternary ammonium compounds. Plant Soil 1983, 70, 303-307. [CrossRef]

32. Dubois, M.; Gilles, K.A.; Hamilton, J.K.; Rebers, P.A.; Smith, F. Colorimetric method for determination of sugars and related substances. Anal. Chem. 1956, 28, 350-356. [CrossRef]

33. Hodges, D.M.; Delong, J.M.; Forney, C.F.; Prange, R.K. Improving the thiobarbituric acid-reactive-substances assay for estimating lipid peroxidation in plant tissues containing anthocyanin and other interfering compounds. Planta 1999, 207, 604-611. [CrossRef] 
34. Blainski, A.; Lopes, G.C.; Palazzodemello, J.C. Application and analysis of the Folin Ciocalteu method for the determination of the total phenolic content from Limonium brasiliense L. Molecules 2013, 18, 6852-6865. [CrossRef] [PubMed]

35. Zhishen, J.; Mengcheng, T.; Jianming, W. The determination of flavonoid contents in mulberry and their scavenging effects on superoxide radicals. Food Chem. 1999, 64, 555-559. [CrossRef]

36. Gil, R.; Bautista, I.; Boscaiu, M.; Lidón, A.; Wankhade, S.; Sánchez, H.; Llinares, J.; Vicente, O. Responses of five Mediterranean halophytes to seasonal changes in environmental conditions. AoB Plants 2014, 6, plu049. [CrossRef] [PubMed]

37. Bradford, M.M. A rapid and sensitive method for the quantitation of microgram quantities of protein utilizing the principle of protein-dye binding. Anal. Biochem. 1976, 72, 248-254. [CrossRef]

38. Beyer, W.F., Jr.; Fridovich, I. Assaying for superoxide dismutase activity: some large consequences of minor changes in conditions. Anal. Biochem. 1987, 161, 559-566. [CrossRef]

39. Aebi, H. Catalase in vitro. Methods Enzymol. 1984, 105, 121-126. [CrossRef] [PubMed]

40. Nakano, Y.; Asada, K. Hydrogen peroxide is scavenged by ascorbate specific peroxidase in spinach chloroplasts. Plant Cell Physiol. 1981, 22, 867-880. [CrossRef]

41. Conell, J.P.; Mullet, J.E. Pea chloroplast glutathione reductase: Purification and characterization. Plant Physiol. 1986, 82, 351-356. [CrossRef]

42. Munns, R.; Tester, M. Mechanisms of salinity tolerance. Annu. Rev. Plant Biol. 2008, 59, 651-681. [CrossRef] [PubMed]

43. Hand, M.; Taffouo, V.; Nouck, A.; Nyemene, K.; Tonfack, B.; Meguekam, T.; Youmbi, E. Effects of salt stress on plant growth, nutrient partitioning, chlorophyll content, leaf relative water content, accumulation of osmolytes and antioxidant compounds in pepper (Capsicum annuum L.) cultivars. Not. Bot. Horti Agrobot. 2017, 45, 481-490. [CrossRef]

44. Badalotti, A.; Anfodillo, T.; Grace, J. Evidence of osmoregulation in Larix decidua at Alpine treeline and comparative responses to water availability of two co-occurring evergreen species. Ann. Forest Sci. 2000, 57, 623-633. [CrossRef]

45. Gower, S.T.; Richards, J.H. Larches: Deciduous conifers in an evergreen world. Bioscience 1990, 40, 818-826. [CrossRef]

46. Schuster, R.; Oberhuber, W. Drought sensitivity of three co-occurring conifers within a dry inner Alpine environment. Trees 2013, 27, 61-69. [CrossRef] [PubMed]

47. Eilmann, B.; Rigling, A. Tree-growth analyses to estimate tree species' drought tolerance. Tree Physiol. 2012, 32, 178-187. [CrossRef] [PubMed]

48. Breda, N.; Huc, R.; Granier, A.; Dreyer, E. Temperate forest trees and stands under severe drought: A review of ecophysiological responses, adaptation processes and long-term consequences. Ann. For. Sci. 2006, 63, 625-644. [CrossRef]

49. Schiop, S.T.; Al Hassan, M.; Sestras, A.F.; Boscaiu, M.; Sestras, E.; Vicente, O. Biochemical responses to drought, at the seedling stage, of several Romanian Carpathian populations of Norway spruce (Picea abies L. Karst). Trees 2017, 31, 1479-1490. [CrossRef]

50. Renault, S. Tamarack response to salinity: Effects of sodium chloride on growth and ion, pigment, and soluble carbohydrate levels. Can. J. For. Res. 2005, 35, 2806-2812. [CrossRef]

51. Santos, C.V. Regulation of chlorophyll biosynthesis and degradation by salt stress in sunflower leaves. Sci. Hort. 2004, 103, 93-99. [CrossRef]

52. Alonso, R.; Elvira, S.; Castillo, F.J.; Gimeno, B.S. Interactive effects of ozone and drought stress on pigments and activities of antioxidative enzymes in Pinus halepensis. Plant Cell Environ. 2001, 24, 905-916. [CrossRef]

53. Croser, C.; Renault, S.; Franklin, J.; Zwiazek, J. The effect of salinity on the emergence and seedling growth of Picea mariana, Picea glauca and Pinus banksiana. Environ. Pollut. 2001, 115, 9-16. [CrossRef]

54. Miron, M.S.; Sumalan, R.L. Physiological responses of Norway spruce (Picea abies [L.] Karst) seedlings to drought and overheating stress conditions. J. Hortic. For. Biotechnol. 2015, 19, 146-151.

55. Munns, R.; Gilliham, M. Salinity tolerance of crops-What is the cost? New Phytol. 2015, 208, 668-673. [CrossRef] [PubMed]

56. Tang, X.; Mu, X.; Shao, H.; Wang, H.; Brestic, M. Global plant-responding mechanisms to salt stress: Physiological and molecular levels and implications in biotechnology. Crit. Rev. Biotechnol. 2015, 35, 425-437. [CrossRef] [PubMed] 
57. Eker, S.; Cömertpay, G.; Konuşkan, Ö.; Ülger, A.C.; Öztürk, L.; Çarmak, İ. Effect of salinity stress on dry matter production and ion accumulation in hybrid maize varieties. Turk. J. Agric. For. 2006, 30, 365-373.

58. Gu, M.F.; Li, N.; Shao, T.Y.; Long, X.H.; Brestič, M.; Shao, H.B.; Li, J.B.; Mbarki, S. Accumulation capacity of ions in cabbage (Brassica oleracea L.) supplied with sea water. Plant Soil Environ. 2016, 62, 314-320. [CrossRef]

59. Peng, Z.; He, S.; Sun, J.; Pan, Z.; Gong, W.; Lu, Y.; Du, X. Na ${ }^{+}$compartmentalization related to salinity stress tolerance in upland cotton (Gossypium hirsutum) seedlings. Sci. Rep. 2016, 6, 34548. [CrossRef] [PubMed]

60. Bogemans, J.; Neirinckx, L.; Stassart, J.M. Effect of de-icing chloride salts on ion accumulation in spruce (Picea abies (L.) sp.). Plant Soil 1989, 113, 3-11. [CrossRef]

61. Maynard, D.G.; Mallett, K.I.; Myrholm, C.L. Sodium carbonate inhibits emergence and growth of greenhouse-grown white spruce. Can. J. Soil Sci. 1996, 77, 99-105. [CrossRef]

62. Al Hassan, M.; Morosan, M.; López-Gresa, M.P.; Prohens, J.; Vicente, O.; Boscaiu, M. Salinity-induced variation in biochemical markers provides insight into the mechanisms of salt tolerance in common (Phaseolus vulgaris) and runner (P. coccineus) beans. Int. J. Mol. Sci. 2016, 17, 1582. [CrossRef] [PubMed]

63. Al Hassan, M.; López-Gresa, M.P.; Boscaiu, M.; Vicente, O. Stress tolerance mechanisms in Juncus: Responses to salinity and drought in three Juncus species adapted to different natural environments. Funct. Plant Biol. 2016, 43, 949-960. [CrossRef]

64. Flowers, T.; Troke, P.F.; Yeo, A.R. The mechanism of salt tolerance in halophytes. Annu. Rev. Plant Physiol. 1977, 28, 89-121. [CrossRef]

65. Greenway, H.; Munns, R. Mechanisms of salt tolerance in non-halophytes. Annu. Rev. Plant Biol. 1980, 31, 149-190. [CrossRef]

66. Kronzucker, H.J.; Britto, D.T. Sodium transport in plants: A critical review. New Phytol. 2011, 189, 54-81. [CrossRef] [PubMed]

67. Lauchli, A.; Wieneke, J. Studies on growth and distribution of $\mathrm{Na}^{+}, \mathrm{K}^{+}$and $\mathrm{Cl}^{-}$in soybean varieties differing in salt tolerance. Z. Pflanzenernaehr. Bodenk. 1979, 142, 3-13. [CrossRef]

68. Verbruggen, N.; Hermans, C. Proline accumulation in plants: A review. Amino Acids 2008, 35, 753-759. [CrossRef] [PubMed]

69. Newton, R.J.; Sen, S.; Puryear, J.D. Free proline changes in Pinus taeda L. callus in response to drought stress. Tree Physiol. 1986, 1, 325-332. [CrossRef] [PubMed]

70. Zamani, M.; Hakimi, M.H.; Mosleh Arany, A.; Kiani, B.; Rashtian, A. Comparing the effects of SNP and SA under salinity stress on proline, sugar, $\mathrm{Na}, \mathrm{K}$ and chlorophyll of leaves of Pinus eldarica and Cupressus sempervirens in Iran. Bull. Environ. Pharmacol. Life Sci. 2014, 3, 91-95.

71. Taïbi, K.; del Campo, A.D.; Vilagrosa, A.; Bellés, J.M.; López-Gresa, M.P.; Pla, D.; Calvete, J.J.; López-Nicolás, J.M.; Mulet, J.M. Drought Tolerance in Pinus halepensis seed sources as identified by distinctive physiological and molecular markers. Front. Plant Sci. 2017, 8, 202. [CrossRef] [PubMed]

72. Ditmarová, L.; Kurjak, D.; Palmroth, S.; Kmet, J.; Strelcová, K. Physiological responses of Norway spruce (Picea abies) seedlings to drought stress. Tree Physiol. 2010, 30, 205-213. [CrossRef] [PubMed]

73. Bonet, A.; Lelu-Walter, M.A.; Faugeron, C.; Gloaguen, V.; Saladin, G. Physiological responses of the hybrid larch (Larix $\times$ eurolepis Henry) to cadmium exposure and distribution of cadmium in plantlets. Environ. Sci. Pollut. Res. Int. 2016, 23, 8617-8626. [CrossRef] [PubMed]

74. Gleeson, D.; Lelu-Walter, M.A.; Parkinson, M. Overproduction of proline in transgenic hybrid larch $($ Larix $\times$ leptoeuropaea $($ Dengler)) cultures renders them tolerant to cold, salt and frost. Mol. Breed. 2005, 15, 21-29. [CrossRef]

75. Rhodes, D.; Hanson, A.D. Quaternary ammonium and tertiary sulfonium compounds in higher-plants. Annu. Rev. Plant Physiol. Mol. Biol. 1993, 44, 357-384. [CrossRef]

76. Khan, M.A.; Ungar, I.A.; Showalter, A.M. The effect of the salinity on the growth, water status, and ion content of a leaf succulent perennial halophyte, Suaeda fruticosa (L.) Forssk. J. Arid Environ. 2000, 45, 73-84. [CrossRef]

77. Katschnig, D.; Broekman, R.; Rozema, J. Salt tolerance in the halophyte Salicornia dolichostachya Moss: Growth, morphology and physiology. Environ. Exp. Bot. 2013, 92, 32-42. [CrossRef]

78. Pardo-Domènech, L.L.; Tifrea, A.; Grigore, M.N.; Boscaiu, M.; Vicente, O. Proline and glycine betaine accumulation in two succulent halophytes under natural and experimental conditions. Plant Biosyst. 2016, 150, 904-915. [CrossRef] 
79. Gagneul, D.; Aïnouche, A.; Duhazé, C.; Lugan, R.; Larher, F.R.; Bouchereau, A. A reassessment of the function of the so called compatible solutes in the halophytic Plumbaginaceae Limonium latifolium. Plant Physiol. 2007, 144, 1598-1611. [CrossRef] [PubMed]

80. Clancy, K.M.; Wagner, M.R.; Reich, P.B. Ecophysiology and insect herbivory. In Ecophysiology of Coniferous Forests; Smith, W.K., Hinckley, T.M., Eds.; Academic Press: San Diego, CA, USA, 1995; pp. 125-180.

81. Rinne, K.T.; Saurer, M.; Kirdyanov, A.V.; Loader, N.J.; Bryukhanova, M.V.; Werner, R.A.; Siegwolf, R.T.W. The relationship between needle sugar carbon isotope ratios and tree rings of larch in Siberia. Tree Physiol. 2015, 35, 1192-1205. [CrossRef] [PubMed]

82. Gil, R.; Boscaiu, M.; Lull, C.; Bautista, I.; Lidón, A.; Vicente, O. Are soluble carbohydrates ecologically relevant for salt tolerance in halophytes? Funct. Plant Biol. 2013, 40, 805-818. [CrossRef]

83. Del Rio, D.; Stewart, A.J.; Pellegrini, N. A review of recent studies on malondialdehyde as toxic molecule and biological marker of oxidative stress. Nutr. Metab. Cardiovasc. Dis. 2005, 15, 316-328. [CrossRef] [PubMed]

84. Al Hassan, M.; Chaura, J.; Donat-Torres, M.P.; Boscaiu, M.; Vicente, O. Antioxidant responses under salinity and drought in three closely related wild monocots with different ecological optima. AoB Plants 2017, 9, plx009. [CrossRef] [PubMed]

85. Kumar, D.; Al Hassan, M.; Naranjo, M.A.; Agrawal, V.; Boscaiu, M.; Vicente, O. Effects of salinity and drought on growth, ionic relations, compatible solutes and activation of antioxidant systems in oleander (Nerium oleander L.). PLoS ONE 2017, 18. [CrossRef] [PubMed]

86. Nxele, X.; Klein, A.; Ndimba, B.K. Drought and salinity stress alters ROS accumulation, water retention, and osmolyte content in sorghum plants. S. Afr. J. Bot. 2017, 108, 261-266. [CrossRef]

87. Mittler, R. Oxidative stress, antioxidants and stress tolerance. Trends Plant Sci. 2002, 7, 405-410. [CrossRef]

88. Caverzan, A.; Casassola, A.; Patussi Brammer, S. Reactive oxygen species and antioxidant enzymes involved in plant tolerance to stress. In Abiotic and Biotic Stress in Plants. Recent Advances and Future Perspectives; Shanker, A., Ed.; InTechOpen: London, UK, 2016; pp. 463-480. [CrossRef]

89. Fini, A.; Brunetti, C.; Di Ferdinando, M.; Ferrini, F.; Tattini, M. Stress-induced flavonoid biosynthesis and the antioxidant machinery of plants. Plant Signal. Behav. 2011, 6, 709-711. [CrossRef] [PubMed]

(C) 2018 by the authors. Licensee MDPI, Basel, Switzerland. This article is an open access article distributed under the terms and conditions of the Creative Commons Attribution (CC BY) license (http:/ / creativecommons.org/licenses/by/4.0/). 